\title{
ASSIMETRIA DE PODER NA CÂMARA SETORIAL DA CITRICULTURA DO MAPA E OS GRUPOS DE INTERESSE CITRÍCOLA ${ }^{1}$
}

\author{
Camilla Silva Geraldello
}

\begin{abstract}
Resumo
O objetivo deste trabalho é compreender como grupos de representação de interesses citrícolas participaram e utilizaram a Câmara Setorial (CS) da Citricultura no Ministério da Agricultura, Pecuária e Abastecimento (MAPA), entre 2004 e 2018, para obter benefícios novos ou manter benefícios existentes. As CS no MAPA são reestabelecidas em 2003 como um foro de interlocução entre os setores público e privado para a definição de políticas para o agronegócio. Assim, tomaram assento nas CS, entidades nacionais representativas dos respectivos setores, que, para o caso da citricultura, inclui produtores de laranja, produtores de mudas, industriais, exportadores e varejistas. Nesse sentido, serão analisadas as atuações dentro da CS e os interesses de três associações: a Associtrus, que representa os produtores de laranja; a Abecitrus, que representou a indústria de suco de laranja de 1988 a 2008; e a CitrusBr, que representa a indústria de suco de laranja desde 2009. Para tanto, será realizada uma análise sobre o surgimento, o papel e as atividades da referida Câmara para, na sequência, avaliar se as ações e decisões tomadas reforçaram ou não o conflito entre citricultores e indústrias por meio da análise da manutenção, obtenção ou perda de benefícios dos dois grupos. Percebeu-se que, devido às assimetrias de informação e de poder entre os grupos, a CS serviu muito mais como um espaço de reivindicação de problemas permanentes do setor, sendo um campo de conciliação para políticas ambientais e fitossanitárias e um campo de conflito para questões econômicas, como um contrato de venda da fruta. Assim, a CitrusBr obteve e manteve benefícios, enquanto a Associtrus, ao ser excluída da CS, perdeu benefícios.
\end{abstract}

Palavras-chaves: Câmara Setorial; MAPA; Citricultura; Grupos de interesse; Ação política do empresariado.

\begin{abstract}
The objective of this paper is to understand how citrus interest groups participated and used the Citrus Sector Chamber (SC) in the Ministry of Agriculture, Livestock and Supply (MAPA) between 2004 and 2018 to obtain new benefits or maintain existing benefits. The CS in MAPA were re-established in 2003 as a forum for dialogue between the public and private sectors for the definition of agribusiness policies. Thus, the CS represented national entities representing the respective sectors, which, in the case of citrus, include orange growers, seedling growers, industrialists, exporters and retailers. In this sense, the actions within the CS and the interests of three associations will be analyzed: Associtrus, which represents the orange growers; Abecitrus, which represented the orange juice industry from 1988 to 2008; and CitrusBr, which has been representing the orange juice industry since 2009. To this end, an analysis will be carried out of the emergence, role and activities of that House to further assess whether or not the actions and decisions taken
\end{abstract}

\footnotetext{
${ }^{1}$ O presente trabalho foi realizado com apoio da Coordenação de Aperfeiçoamento de Pessoal de Nível Superior - Brasil (CAPES) - Código de Financiamento 001; e sua versão inicial foi apresentada no IX Seminário Discente do Programa de Pós-Graduação em Ciência Política da FFLCH-USP. Agradeço aos professores Fernando Abrucio e Wagner Pralon Mancuso pelos comentários durante o evento e aos pareceristas da RECP.

2 Doutoranda em Ciência Política pela FFLCH/USP. Professora de Relações Internacionais no Centro Universitário Moura Lacerda - Ribeirão Preto/SP. Graduada pela Unesp-Marília e mestra em Relações Internacionais pelo programa San Tiago Dantas (Unesp-Unicamp-PUC-SP). É membro de grupos de pesquisa ligados ao estudo de política externa e Estados Unidos, como a Rede de Pesquisa em Política Externa e Regionalismo (REPRI).Contato: camillageraldello@gmail.com.
} 
have reinforced the conflict between farmers and industries through the analysis of maintenance, gain or loss of benefits of both groups. Due to the asymmetries of information and power between the groups, CS was much more a space for claiming permanent problems of the sector, being a conciliation field for environmental and phytosanitary policies and a conflict field for issues, such as a fruit sale contract. Thus, CitrusBr obtained and maintained benefits, while Associtrus, when excluded from CS, lost benefits.

Key-words: Sectorial Chamber; MAP; Citrus; Interest groups; Political action of the entrepreneurs.

\section{Resumen}

El objetivo de este trabajo es comprender cómo los grupos de interés cítricos participaron y utilizaron la Cámara Sectorial de la Agricultura (CS) en el Ministerio de Agricultura, Ganadería y Abastecimiento (MAPA) entre 2004 y 2018 para obtener nuevos beneficios o mantener los beneficios existentes. Las CS en MAPA se restablecieron en 2003 como un foro de diálogo entre los sectores público y privado para la definición de políticas de agronegocios, por lo que representaron entidades nacionales que representan a los respectivos sectores, que, en el caso de los cítricos, incluyen productores de naranjas, productores de plántulas, industriales, exportadores y minoristas. En este sentido, se analizarán las acciones dentro del CS y los intereses de tres asociaciones: Associtrus, que representa a los productores de naranja; Abecitrus, que representó a la industria del jugo de naranja de 1988 a 2008; y CitrusBr, que ha estado representando a la industria del jugo de naranja desde 2009. Con este fin, se llevará a cabo un análisis del surgimiento, el papel y las actividades de esa Cámara para evaluar aún más si las acciones y decisiones tomadas han reforzado el conflicto entre agricultores e industrias a través del análisis de mantenimiento, ganancia o pérdida de beneficios de ambos grupos. Debido a las asimetrías de información y poder entre los grupos, la CS fue mucho más un espacio para reclamar acerca de problemas permanentes del sector, siendo un campo de conciliación para políticas ambientales y fitosanitarias y un campo de conflicto para problemas, como un contrato de venta de frutas. Por lo tanto, CitrusBr obtuvo y mantuvo beneficios, mientras que Associtrus, cuando se excluyó de CS, perdió beneficios.

Palabras clave: Cámara Sectorial; Mapa; Citricultura; Grupos de interés; Acción política de los empresarios.

\section{INTRODUÇÃO}

A citricultura no Brasil nasce e consolida-se entre as décadas de 1920 e 1940, passando por diversas crises (econômicas e fitossanitárias ${ }^{3}$ ) e por disputas entre as entidades representativas do setor, que cresceram ou morreram com as oscilações de seu principal produto: o suco de laranja concentrado e congelado, cujas vendas são ancoradas ao consumo externo ${ }^{4}$ e que enfrenta barreiras de importação do maior mercado nacional consumidor do produto (os Estados Unidos). Apesar desses fatores, o Brasil é líder mundial na venda de suco de laranja desde os anos 1980, posição que vem sendo defendida por todos os elos da cadeia.

\footnotetext{
${ }^{3} \mathrm{O}$ termo fitossanitário é referente a aspectos relacionados aos vegetais e pode englobar um conjunto de medidas para preservação dos mesmos (MIRANDA; CUNHA FILHO; BURNQUIST; BARROS, 2004). Neste trabalho, o termo "crise fitossanitária" indica, na maior parte das vezes, que os pomares citrícolas estavam ameaçados pela propagação de patógenos e doenças nas árvores.

${ }^{4}$ Somente $\%$ da produção é consumida domesticamente. (FAVA NEVES et al, 2010)
} 
Fator crucial para a proeminência do setor internacionalmente foi (e ainda é) o auxílio estatal, que pode ser percebido no desenvolvimento do complexo no Estado de São Paulo. Primeiramente, com a criação do Serviço de Citricultura e das Estações Experimentais pelo governo paulista na década de 1920; e pela tentativa do governo paulista de estabelecimento de preço mínimo para a caixa da fruta entre 1940 e 1950. Apesar da década de 1960 ser marcada pela formação da indústria de suco com capital próprio do setor (nacional e estrangeiro) e sem capital público, a década de 1970 será marcada por crises econômica e fitossanitária e mudanças na forma de representação de produtores e processadoras com a criação de associações de caráter privado específicas para o setor, estimuladas pelo governo federal. Assim, em 1974, a "Campanha Nacional Contra o Cancro Cítrico" (CNCC) vai levar à criação da Associação Paulista dos Citricultores (Associtrus) e da Associação Brasileira da Indústria de Suco Cítricos (Abrassucos), pois a participação dos citricultores na CNCC deveria ocorrer por meio de associações. (BORGES; COSTA, 2005/2006; PAULILLO, 2006; RODRIGUES, 1995)

Já as décadas de 1980, quando se alcança o quase monopólio global e uma nova forma de contrato de compra da laranja ${ }^{5}$, e 1990, são marcadas pela ausência da participação ou mediação do Estado federal, o que acarreta a concentração e redução do número de indústrias, ao investimento das indústrias em pomares próprios, à queda na qualidade das frutas e ao aumento no conflito entre processadoras e citricultores sobre o preço da caixa de laranja. Todavia, entre os anos 1990 e 2000, novas crises econômica e fitossanitária (a chegada do greening ao Brasil em 2004) ocasionaram uma reestruturação do setor e um retorno discreto da atuação do governo federal e estadual: com a criação das Câmaras Setoriais (CS) da Citricultura na Secretaria de Agricultura e Abastecimento do Estado de São Paulo (SAA-SP), em 1997, e no Ministério da Agricultura, Pecuária e Abastecimento (MAPA), em 2004. (BORGES; COSTA, 2005/2006; PAULILLO, 2006).

Ressalta-se que, desde os anos 1970, o Estado tem procurado resolver problemas de ordem econômica ou fitossanitária, todavia, somente os problemas fitossanitários têm obtido soluções. Os problemas de ordem econômica, notadamente concessão de crédito e endividamento de citricultores e estabelecimento de um valor considerado justo por todos os elos da cadeia para a caixa da laranja (por um novo contrato de venda da fruta), não conseguem soluções satisfatórias.

\footnotetext{
${ }^{5}$ Esse contrato ficou conhecido como "contrato padrão", o qual atrelava "o preço da caixa da laranja à média anual do preço de mercado registrado pela Bolsa de Valores de Nova Iorque. Assim, os produtores poderiam participar das oscilações dos preços decorrentes das geadas da Flórida.” (BORGES; COSTA, 2005/2006, p. 112)
} 
Nesse sentido, um dos lócus de interlocução entre governo e elos do complexo citrícola, a Câmara Setorial da Citricultura no MAPA foi um dos cenários no qual as disputas entre citricultores, representados pela Associtrus, e indústrias, representadas pela Associação Brasileira dos Exportadores de Cítricos (Abecitrus) até 2005 e pela Associação Nacional dos Exportadores de Sucos Cítricos (CitrusBr) a partir de 2010, ocorreram. O objetivo deste trabalho é, então, compreender como grupos de representação de interesses citrícolas participaram e utilizaram a CS da Citricultura no MAPA entre 2004 e 2018 para obter benefícios novos ou manter benefícios existentes. Para tanto, foram analisadas as origens das CS e da CS da Citricultura no MAPA. Na sequência, foi realizado um levantamento das Atas da CS da Citricultura ${ }^{6}$ e por meio da análise de conteúdo se verificou se a CS possibilitou que as associações mantivessem, ganhassem ou perdessem benefícios. Percebeu-se que, com a chegada da CitrusBr, os consensos na CS acerca do estabelecimento de um preço justo para a caixa da laranja e sobre a demanda mundial existente do suco de laranja diminuíram, nesse sentido, a abordagem teórica utilizada procurou refletir sobre as formas de atuação política empresarial. Isso porque, desde os anos 1980, as grandes indústrias citrícolas são os atores que detêm o maior poder financeiro na rede de poder citrícola e por meio de suas associações de representação de interesses conseguiram expandir seus recursos políticos e organizacionais, tornando-se os atores mais poderosos da rede de poder citrícola (PAULILLO, 2006).

\section{AS CÂMARAS SETORIAIS NO BRASIL: ORIGENS E ASPECTOS TEÓRICOS}

As Câmaras Setoriais em âmbito nacional surgem no final dos anos 1980, em meio à crise fiscal doméstica e à nova reconfiguração do cenário internacional que demandavam uma redefinição do papel do Estado, a integração do Brasil nessa nova ordem global e alterações na articulação entre Estado e sociedade (STADUTO et al, 2007). Inicialmente, o Decreto 96.056, de 19 de maio de 1988, reorganizou o Conselho de Desenvolvimento Industrial (CDI) ${ }^{7}$ e a Resolução

\footnotetext{
${ }^{6}$ Infelizmente, somente obtivemos acesso às Atas a partir da $11^{a}$ Reunião Ordinária (ocorrida em 29/10/2007), pois as Atas de 2004 a 2006 não estão em arquivo eletrônico. Agradecemos ao atual secretário da CS, Marconi Lopes de Albuquerque, pelo envio das Atas.

${ }^{7} \mathrm{O}$ órgão foi criado em abril de 1964 pelo presidente Castelo Branco para promover e regular as atividades industriais do país com o nome de Comissão de Desenvolvimento Industrial. "A comissão deveria constituir-se em uma instância hierárquica superior na cadeia burocrática de decisões sobre política industrial, agregando os grupos executivos, setorialmente especializados, em uma mesma jurisdição administrativa. Idealmente, deveria formular uma política abrangente de investimento industrial, com uma clara hierarquia de prioridades, a ser, então, implementada setorialmente pelos grupos. A maior compatibilização e articulação entre os diferentes objetivos setoriais expressos pelos grupos executivos resultaria da centralização do processo decisório e da descentralização da implementação das políticas" (ABRANCHES, 2009). Todavia, durante a Ditadura Militar (1964-85) a CDI serviu mais como uma "correia
} 
SDI n. 13, de 12 de julho de 1989, efetivou a criação das Câmaras Setoriais, visando a constituição de uma câmara tripartite entre governo, indústrias e trabalhadores para discutir a política industrial do país ${ }^{8}$. Entretanto, apenas em março de 1991 a participação dos trabalhadores foi incluída e as CS passaram a funcionar totalmente, buscando "promover acordos [e] caminhos para superar a crise do setor industrial”' (TAKAGI, 2000, p.10). Assim, se nos anos 1980 as CS do setor industrial atuaram muito mais no combate à inflação que sobre as políticas para o setor, nos anos 1990 as CS serão propostas para auxiliar o gerenciamento de preços (STADUTO ET AL, 2007).

É em meio a esse contexto que são criadas as CS no Ministério da Agricultura por meio da Lei n. 8.171, de 17 de janeiro de 1991, a Lei Agrícola. (RISSARDI JR., SHIKIDA, LAGES, 2017; STADUTO et al, 2007; TAKAGI, 2000). Segundo Takagi (2000), a Lei Agrícola era vista como uma necessidade por membros do Ministério da Agricultura e de lideranças do agronegócio, devido à "crise do modelo de Estado interventor [nos anos 1980] e das políticas agrícolas até então implementadas, que estavam extremamente debilitadas" (TAKAGI, 2000, p. 15). O que levou ao aumento da pressão de diversas associações nacionais de produtores para participar das decisões de política agrícola nacionais. Ou seja, a nova política agrícola deveria incluir as lideranças do agronegócio nas decisões e o Estado deveria diminuir seu papel. Desse modo, o modelo liberal implementado no começo dos anos 1990, com seus cortes orçamentários, ia em direção ao desejado pelo setor, sendo complementado pela criação do Conselho Nacional de Política Agrícola (CNPA) e das Câmaras Setoriais (respectivamente, Resoluções n. 1, de 21 de março de 1991 e n. 2, de 08 abril de 1991), institucionalizando a "participação dos grupos de pressão nos fóruns de discussão e decisão das políticas agrícolas" (TAKAGI, 2000, p.15). Tanto o CNPA quanto as CS serviriam como espaço de divisão de responsabilidades entre governo e setor privado, tendo "de um lado o [setor] público com objetivo de tornar suas políticas legítimas e do outro, o [setor] privado, que busca constantemente um ambiente institucional favorável às suas atividades" (STADUTO et al, 2007, p.12). Para Anderson (1999), as CS promoveriam o acesso de grupos mais organizados em detrimento de grupos menos organizados ao Estado ao mesmo tempo em que rompiam com o corporativismo tradicional no Brasil, gerando uma nova dinâmica de convergência.

Nesse primeiro momento, para além das CS por produtos, que totalizaram 35 até 1995, foram criadas variadas câmaras temáticas que se sobrepunham umas sobre as outras, banalizando

de transmissão para decisões tomadas por outras agências, mais poderosas, de formulação da política econômica, no âmbito ora do Ministério do Planejamento, ora do Ministério da Fazenda" que como instância máxima na definição da política industrial. (ABRANCHES, 2009)

${ }^{8}$ A primeira CS criada foi no setor automotivo. Ver Arbix (1995). 
o uso das CS, o que, juntamente com os reveses sofridos pela Lei Agrícola, acarretou no término das reuniões da CNPA em 1993 e, em 1995, no fim das reuniões das CS, as quais foram desativadas. Entre os reveses descritos por Takagi (2000), encontram-se problemas semelhantes à CDI da Ditadura Militar - a concentração da definição da política agrícola pelos órgãos governamentais sem as contribuições das associações de representação de interesses, entre as quais a Confederação da Agricultura e Pecuária do Brasil (CNA), a Organização das Cooperativas Brasileiras (OCB), a Sociedade Rural Brasileira (SRB) e a Confederação Nacional dos Trabalhadores na Agricultura $(\text { Contag) })^{9}$, transformando a CNPA e as CS em instâncias ratificadoras das políticas previamente definidas pelo governo. Por seu turno, o governo alegava que as reuniões das CS tinham um caráter reivindicativo para os grupos de interesse, que não assumiam o papel de parceiros ao não se comprometerem e exigirem recursos e ação governamentais. Cabe destacar ainda o argumento de Anderson retomado por Gonçalves et al (2009) de que "desde o início, as funções das [CS] não foram bem definidas, o que sempre deixou margem para a mudança de rumo de suas ações sempre que atendesse aos interesses majoritários”.

Fator relevante para compreender o esvaziamento e fim das CS nos anos 1990 é a retração na atuação do Estado em oposição ao aumento do papel do setor privado no agronegócio.

\footnotetext{
[C]om a estabilização da economia [após o Plano Real], o setor privado passa a cumprir um papel mais ativo na oferta de crédito, comercialização e estocagem de produtos agrícolas. O Estado, por sua vez, retira-se de seu tradicional papel de tabelar preços, gerenciar a produção, regular e monopolizar as atividades comerciais. As reformas políticas implantadas forçaram uma melhor alocação de recursos, aumento de produtividade, melhoria da qualidade dos produtos e redução dos preços dos alimentos. Entretanto, altas taxas de juros, infraestrutura física inadequada e sistema tributário ineficiente impediram uma maior expansão do setor agrícola (HELFAND; REZENDE, 2001 apud MOURA; BRISOLA, 2010, p.6-7).
}

Tal papel do setor privado foi possível em decorrência: 1) dos recordes ano a ano que, desde os anos 1990, a produção agrícola alcançou, com maior intensidade a partir de 2000; 2) da aderência dos preços agrícolas ao câmbio flutuante a partir de 2002, ocasionando uma elevação dos preços; e 3) das liberalizações do mercado agrícola brasileiro realizadas em 1988 e 1989 favorecidas por negociações internacionais em andamento - a criação do Mercado Comum do Sul (Mercosul) e a Rodada Uruguai, com a consequente criação da Organização Mundial do Comércio (OMC) (MACHADO, 2009). Contudo, conforme supracitado, o setor agrícola ainda enfrentava dificuldades domésticas para continuar se expandindo.

\footnotetext{
${ }^{9}$ Presente somente em algumas CS.
} 
Desta forma, com o aumento da produtividade e da competitividade no mercado externo do agronegócio brasileiro no início do século XXI, o setor volta a pressionar e a demandar do Estado brasileiro, o qual, por sua vez, retoma seu papel "como promotor de ações diretas e indiretas na busca de soluções para os problemas fitossanitários e de integração entre os vários segmentos e organismos" (BORGES; COSTA, 2005, p.18). Um ensaio a essa retomada ocorreu ainda em setembro de 1998 por meio da criação do Conselho do Agronegócio (Consagro), "com a missão de proceder à articulação e negociação entre o setor público e a iniciativa privada, com o objetivo de implementar os mecanismos, as diretrizes e as estratégias competitivas do agronegócio" (LESSINGER, 2003). Porém, o Consagro não convocou mais reuniões após julho de 1999.

A retomada com força do papel do Estado como promotor de ações diretas e indiretas no agronegócio ocorreria em 2003, quando a agricultura volta a figurar entre as prioridades do Estado brasileiro, tendo duas metas principais: "a geração de empregos, sobretudo com o estímulo à agricultura familiar, e a produção de excedentes exportáveis, com a conquista da fronteira agrícola, agregação de valor e com aumento da capacidade de negociação do Brasil nas relações bi e multilaterais" (RODRIGUES INSTALA..., 2003) ${ }^{10}$. Para alcançar a segunda meta, que acarretou na retomada das ações do Estado, a interlocução com grupos de interesse foi facilitada com a nomeação de Roberto Rodrigues ${ }^{11}$ para o MAPA em janeiro de 2003.

Já em fevereiro de 2003, Rodrigues anunciou a reativação do Consagro, visando unir setor público e privado na elaboração da política agrícola. Juntamente com esse anúncio, Rodrigues assegurou que as propostas apresentadas no Consagro seriam discutidas em Câmaras Setoriais específicas antes de serem discutidas em suas reuniões (CONSELHO DO..., 2003). Poucos meses depois, em maio de 2003, Rodrigues também anunciou a recriação do Conselho Nacional de Política Agrícola (CNPA), com três eixos centrais de atuação: políticas públicas, organização privada e negociações internacionais (MAPA RECRIARÁ..., 2003). Nessa perspectiva, a política agrícola adotada desde 2003 pelo MAPA teve a estrutura conforme exposto na figura 1:

Imagem 1 - Relação entre CS, Consagro e CNPA no MAPA (2003-2018)

\footnotetext{
${ }^{10}$ Esses dois caminhos tinham sido percebidos por alguns analistas, como Veiga (2002).

${ }^{11}$ Rodrigues, além de agrônomo e produtor de soja, cana, laranja e pecuária de corte, esteve desde os anos 1980 em diversas instâncias de associações de representação de interesses do agronegócio, passando pela diretoria da Organização das Cooperativas do Estado de São Paulo (OCESP), da Organização dos Plantadores de Cana do Estado de São Paulo (ORPLANA) e da Sociedade Rural Brasileira (SRB); pela vice-presidência da Sociedade Nacional de Agricultura (SNA) e da Organização das Cooperativas Americanas; pela presidência da Organização das Cooperativas Brasileiras (OCB) e da Aliança Mundial de Cooperativas; e pela secretaria da Frente Ampla da Agropecuária Brasileira (FAAP) (MENDONÇA, 2005).
} 
(3)

$$
\begin{aligned}
& \text { Os orgãos competentes } \\
& \text { devolvem a solução para } \\
& \text { a CGAC que por sua vez } \\
& \text { responde à câmara }
\end{aligned}
$$

\section{(2)}

CGAC Identifica o or-
ganismo ou órgão res-
ponsável e encaminha a
proposta.

\section{(1)}

$$
\begin{aligned}
& \text { Cada Câmara, em am- } \\
& \text { biente de atuação, } \\
& \text { identifica os problemas, } \\
& \text { discute internamente e } \\
& \text { encaminha a proposta } \\
& \text { de solução à CGAC }
\end{aligned}
$$
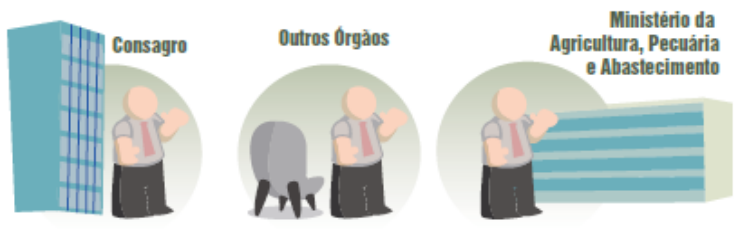

3
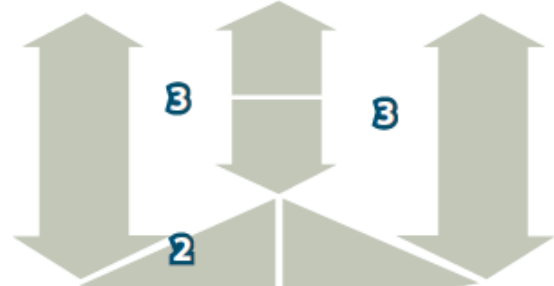

\section{GGAC}

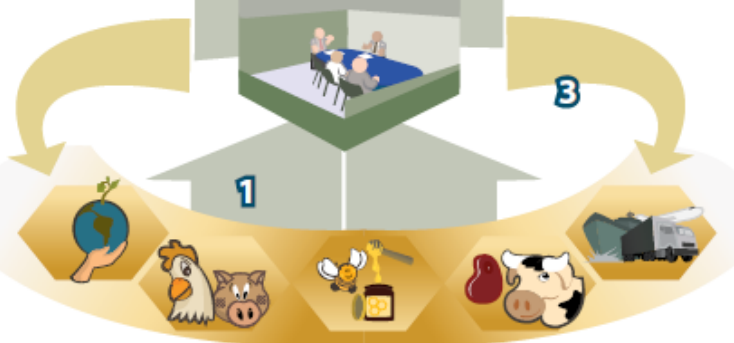

\section{Câmaras Setoriais e Temáticas}

*CGAC: Coordenação-Geral de Apoio às Câmaras Setoriais e Temáticas

Fonte: BRASIL, 2009, p. 13.

Por meio da figura 1, percebe-se que as CS e temáticas tinham como intuito formar a base "para a identificação de oportunidades ao desenvolvimento das cadeias produtivas, definindo ações prioritárias de interesse para o agronegócio brasileiro e seu relacionamento com os mercados interno e externo" (VILELA; ARAÚJO, 2006, p.7). Para a instalação de uma CS, o MAPA identifica setores ou temas com importância socioeconômica e, então, "convida instituições e órgãos de governo a indicar um representante titular naquela Câmara. As instituições devem ser de caráter nacional e representativas do setor ou tema em questão" (BRASIL, 2009, p.15), o que corrobora com a participação dos diferentes elos das cadeias produtivas - "insumos, produtores, indústrias, distribuidores, consumidores, além de organizações que apoiam as operações da cadeia produtiva, como instituições de pesquisa, financeiras, poderes públicos [...], dentre outros" (MOURA; BRISOLA, 2010, p.9). Com isso, o Estado garante informações de "qualidade e atualizadas sobre o desenvolvimento das diferentes cadeias produtivas" (STADUTO ET AL, 2007, p.12). 
A maior parte das CS que existem hoje foram criadas entre 2003 e 2006, período de nascimento de 24 das 31 CS que constam no site do MAPA (em dezembro/2019) ${ }^{12}$. Essa grande quantidade de CS pode ser explicada por outro aspecto levantado por Staduto et al (2007, p.13): como as CS valorizam o agronegócio, passa-se "a ideia de que suas ações podem elevar a reputação de seus setores, e isso faz com que o crescimento e o desenvolvimento aconteçam, já que as ações propostas pelas [CS] tendem a ser executadas". Todavia, apesar do modelo proposto em 2003 contemplar todos os elos da cadeia representada na CS, muitas vezes as associações de representação dos trabalhadores rurais não foram incluídas. Além disso, mesmo com a interlocução do governo, as CS refletem os problemas de cada complexo agroindustrial, como apontado por Guanziroli, Basco e Ortega (2007), que, ao analisarem as CS do MAPA entre 2002 e 2006, elaboram uma tipologia para classificá-las:

- Câmaras Reivindicativas: nas quais não se efetua análise dos entraves das cadeias nem se produzem propostas estratégicas. Limitam-se a exigir do Estado uma série de reivindicações;

- Câmaras Proativas: possuem conhecimento dos entraves das cadeias e fazem propostas de estruturação e de longo prazo para o setor;

- Câmaras Inativas: são as que têm mais presença governamental e que funcionam pouco ou estão em fase de extinção. (GUANZIROLI; BASCO; ORTEGA, 2007, p.7, grifos no original).

Os autores também categorizaram as CS segundo o grau de articulação das cadeias agroindustriais representadas e se tal articulação (ou sua falta) reflete no funcionamento das CS. Existiriam assim cinco formas de organização das cadeias agroindustriais representadas nas CS do MAPA. No primeiro tipo, os Casos de Produção Integrada que se auto regula, as cadeias agroindustriais contam "com mecanismos internos de regulação de tipo contratual que visam diminuir custos de transação na produção e na comercialização" (GUANZIROLI; BASCO; ORTEGA, 2007, p.9). Algumas possuem acordos muito formais (cadeias do Fumo e do Frango), outras possuem acordos um pouco menos formais (cadeias da Viticultura e de Flores e Plantas Ornamentais).

\footnotetext{
${ }^{12}$ As CS são Açúcar e Álcool; Algodão; Animais de Estimação; Arroz; Aves e Suínos; Borracha Natural; Cacau; Cachaça; Caprinos e Ovinos; Carne Bovina; Cerveja; Citricultura; Culturas de Inverno; Equideocultura; Erva-Mate; Feijão e Pulses; Fibras Naturais; Flores e Plantas Ornamentais; Florestas Plantadas; Fruticultura; Hortaliças; Leite e Derivados; Mandioca; Mel e Produtos das Abelhas; Milho e Sorgo; Oleaginosas e Biodiesel; Palma de Óleo; Produção e Indústria de Pescados; Soja; Tabaco; e Viticultura, Vinhos e Derivados. Já as Câmaras Temáticas são Agricultura Orgânica; Agricultura Sustentável e Irrigação; Crédito, Seguro e Comercialização do Agronegócio; Infraestrutura e Logística do Agronegócio; Insumos Agropecuários; e Sistema Brasileiro de Inspeção de Produtos de Insumos Agropecuários (SISBI) do SUASA. Disponível em <http://www.agricultura.gov.br/assuntos/camaras-setoriaistematicas/camaras-setoriais-1 $>$ e $<$ http://www.agricultura.gov.br/assuntos/camaras-setoriais-tematicas/camarastematicas $>$. Acesso em 04 dezembro de 2019.
} 
Já o segundo tipo, são os Casos de Commodities que possuem instâncias para regular o mercado. Isso ocorre quando "instâncias regulatórias próprias (instituições) [foram criadas pelos elos da cadeia agroindustrial] de forma a diminuir assimetrias de informação e custos de transação" (GUANZIROLI; BASCO; ORTEGA, 2007, p.10). O exemplo mais antigo é da cadeia do Açúcar e Álcool que foi seguido pela cadeia da Cachaça. No terceiro tipo, tanto o mercado nacional quanto o internacional é que regulam os preços dos produtos, são os Casos de Commodities que se regulam pelo mercado, representadas pelas cadeias do Trigo; de Oleaginosas e Biodiesel; de Borracha Natural; e do Cacau.

Como quarto tipo, estão os Casos de Commodities que tem problemas de regulação. Nessas cadeias agroindustriais que "não conseguiram ainda se autorregular, nem através da criação de instituições próprias nem tampouco pelo mercado. A regulação nesses casos recai sobre o Estado" (GUANZIROLI; BASCO; ORTEGA, 2007, p.12). As cadeias do Milho; do Arroz; e da Citricultura têm tais problemas. Por fim, no quinto tipo, estão os Casos de difícil regulação, como as cadeias de Hortaliças e a Orgânicos e da Agricultura Orgânica por tratarem-se de setores altamente heterogêneos, com mais de 75 espécies na mesma cadeia.

Todavia, em decorrência da “incorporação de grupos organizados nos aparelhos do Estado" (TAKAGI, 2000, p.70), boa parte da literatura que aborda as CS utiliza o corporativismo ou neocorporativismo como base teórica (ARBIX, 1996; DINIZ, 1993; DINIZ; BOSCHI, 2000; MARTIN, 1996; MOURA; BRISOLA, 2010; RISSARDI JR ET AL, 2017; RODRIGUES, 1995; 1999; TAKAGI, 2000) ${ }^{13}$. Schmitter (1974) foi quem se destacou pioneiramente por descrever essa relação estruturada e cooperativa entre o governo e grupos de interesse. Segundo o autor, o corporativismo

[...] pode ser definido como um sistema de representação de interesse no qual as unidades constituintes [associações de interesses] estão organizadas em um número limitado de categorias singulares, obrigatórias, não competitivas, ordenadas hierarquicamente e diferenciadas funcionalmente, reconhecidas ou licenciadas (se não criadas) pelo Estado, que concedeu um monopólio representacional deliberado dentro [dos respectivos setores] em troca de manter certos controles sobre a seleção [dos líderes e da] articulação de demandas e apoios [dessas associações]. (SCHMITTER, 1974, p.93-4, tradução nossa).

Assim, existiriam duas incidências dessa intermediação (subtipos de corporativismo): o estatal, presente em governos autoritários e fascistas; e o societal (ou neocorporativista), que seria

\footnotetext{
${ }^{13}$ Outra parte considerável da literatura utiliza a Nova Economia Institucional (NEI) (STADUTO ET AL, 2007; SILVA; STAUDT; VERDI, 2009).
} 
uma versão mais "moderna" do corporativismo por pressupor acordos barganhados e agentes nãoestatais com autonomia relativa (SCHMITTER, 1979). Embora compartilhem premissas semelhantes $^{14}$, os dois subtipos são produtos de processos políticos, sociais e econômicos diferentes, dependendo da maneira como ocorreu a conquista da representação setorial: de forma independente no neocorporativismo ou via concessão estatal de forma dependente e imposta no corporativismo (SCHMITTER, 1974) ${ }^{15}$.

Vinha (1999, p. 18) argumenta que "o neocorporativismo [...] não se aplica ao caso brasileiro, senão em segmentos específicos". Assim, para alguns setores, o modelo pode ser aplicado, caso do papel e celulose estudado pela autora, e na "constituição das Câmaras Setoriais" (DINIZ; BOSCHI, 2000, p. 9). Nesse sentido, as CS seriam representações do neocorporativismo, já que o neocorporativismo promove o sistema de representação de interesse baseado na emergência controlada dos grupos, os quais serão limitados e estratificados verticalmente, levando a uma interdependência complementar. Para cada função ou interesse existem as "peak associations" ${ }^{16}$, ocasionando monopólios na representação de interesses concedidos pelo próprio Estado, em troca de determinados comportamentos compatíveis com a visão governamental (SCHMITTER, 1979). Desse modo, o neocorporativismo pode ser resumido em três pontos centrais:

\begin{abstract}
a expansão de organizações de interesse centralizadas que detêm o monopólio de representação; o reforço das relações entre o Estado e essas organizações; e a consolidação de negociações tripartites envolvendo organizações sindicais e empresariais, em coordenação com as políticas governamentais. (PONT, 2012, p.221).
\end{abstract}

Entretanto, no Brasil foi implantado

o corporativismo de Estado, de teor restrito, segmentado e de baixo poder de incorporação. Esse sistema promoveu a participação dos empresários na estrutura decisória das comissões e dos conselhos econômicos integrados à burocracia governamental, entre os anos 30 e 80 , mas excluiu os trabalhadores, presentes apenas em alguns órgãos ligados às questões trabalhistas e previdenciárias. Consolidou-se [no país] um corporativismo setorial e bipartite, destituído de arenas multissetoriais de negociação

\footnotetext{
14 Tais premissas são 1) o número limitado; 2) a singularidade; 3) a compulsoriedade; 4) a não competitividade; 5) a ordenação hierárquica; 6) a diferenciação funcional; 7) o reconhecimento do Estado; 8) o monopólio de representação; e 9) o controle sobre seleção de liderança e articulação de interesse. (SCHMITTER, 1974, p.103-4).

15 Para mais diferenças entre os dois modelos, ver Viscardi (2018).

${ }^{16}$ Segundo Schmitter (1993, p.13), peak associations podem ser consideradas como "associações de associações", ou seja, representam categorias mais abrangentes tentando "coordenar o comportamento de entidades dentro de um único setor (por exemplo, toda a indústria química), todo um ramo de produção (por exemplo, toda a indústria) ou a classe como um todo (todos capitalistas, trabalhadores ou agricultores, independentemente de ramo ou setor)" (tradução nossa). Como exemplo, no Brasil tem-se a CNA e a Confederação Nacional da Indústria (CNI).
} 
e de espaços de interlocução capital-trabalho, desestimulando a aglutinação de interesses. (DINIZ, 1999, p.165)

Conquanto as CS sejam consideradas exceções ao corporativismo setorial brasileiro por seu caráter tripartite (DINIZ; BOSCHI, 2000), no caso da CS da Citricultura, as associações de trabalhadores não participaram da maior parte das reuniões da CS e, como será visto na seção seguinte, não há um equilíbrio de forças de classe entre capital e trabalho dentro do complexo citrícola: há uma situação oligopsônica, na qual a indústria processadora é a grande beneficiária. Nessa perspectiva, o neocorporativismo apresenta lacunas para explicar a relação entre grupos de interesse e Estado na formulação de políticas públicas dentro das CS, pois, conforme apontado por Schmitter (2010), em poucos lugares e por pouco tempo o neocorporativismo foi praticado devido à oposição de interesses empresariais organizados.

Como explicado por Mancuso (2007), o sistema neocorporativista de representação de interesses no Brasil teria gerado uma "dificuldade crônica de constituir e manter ações coletivas em torno de propostas unificantes" (MANCUSO, 2007, p.134) tanto intra quanto extrassetorial, o que para alguns autores, como Schneider (2004), levaria à fraqueza política da ação coletiva dos grupos de interesse empresariais. Esse fenômeno ocorre por duas razões: “(i) porque engendram entidades setoriais de grau superior, cujos líderes não são representativos e (ii) porque não prevêem uma entidade de cúpula multissetorial” (MANCUSO, 2007, p.135). Assim, se entre o fim da década de 1970 e o início dos anos 1990 o empresariado "soube utilizar-se simultaneamente dos diferentes canais disponíveis, como os órgãos de classe (ou seja, as entidades dos sistemas corporativo e extracorporativo), os 'anéis burocráticos ${ }^{17}$ e os contatos pessoais diretos com os tomadores de decisão" (MANCUSO, 2007, p.134), mesmo com as macrotransformações ocorridas no Brasil nos anos 1980 e 1990 (democratização e reforma de mercados), a continuidade da interação entre empresariado e governo persiste, principalmente devido ao boom das commodities dos anos 2000 (SCHMITTER, 2010).

Mancuso (2007) identifica duas abordagens acerca da atuação do empresariado como ator político no Brasil a partir de meados dos anos 1990 até hoje: uma que alega ser a fraqueza política dos empresários, fruto do sistema corporativista de representação de interesses, e outra que não vê nesse sistema um óbice para a força política do segmento empresarial. Para os autores que acreditam ser o sistema corporativista um problema, esse sistema incapacitaria o empresariado de

\footnotetext{
${ }_{17}$ Cavalcante, Lotta e Oliveira (2018, p.59) relembram que o conceito se refere a "órgãos com fortes prerrogativas burocráticas e de insulamento, que [possuem] estreita articulação com setores específicos da sociedade [...], sobretudo da emergente burguesia industrial".
} 
"exercer o papel de liderança que deveria assumir" (MANCUSO, 2007, p.135) após as macrotransformações dos anos 1980 e 1990. Já para os que acreditam na força do empresariado, não obstante a existência do sistema corporativista, esse sistema tem-se mostrado "capaz de assumir o papel do 'empreendedor político' - ou seja, o ator que decide, por conta própria, assumir o custo necessário para deflagrar e organizar a ação coletiva, com vistas à provisão do benefício desejado por todos" (MANCUSO, 2007, p.137), sendo as macrotransformações o fator mobilizador para a ação de empresários organizados em entidades corporativistas.

Iglecias (2007) destaca que

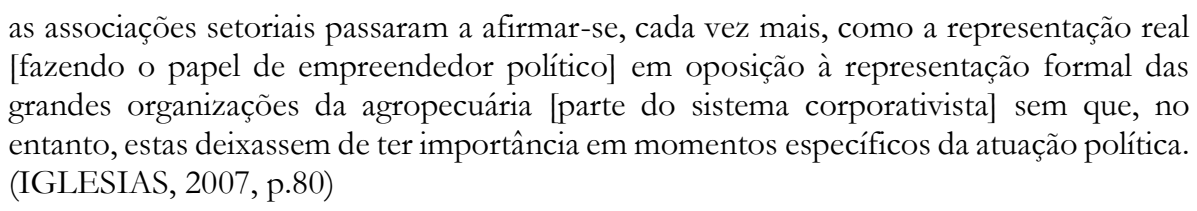

CNA, OCB e SRB são algumas das grandes organizações da agropecuária brasileira que mantém a importância em momentos específicos, como as CS. Entretanto, dentro e fora das CS as representações setoriais possuem atuações centrais nas questões por produto e a CS da Citricultura é exemplo: dadas as dificuldades na regulação do setor, a CS funciona "como [caixa] de ressonância do setor privado, canalizando pressões e ajudando a legitimar as tomadas de decisão da burocracia estatal" (IGLECIAS, 2007, p.82). Assim, cada entidade extracorporativista (Associtrus, Abecitrus e CitrusBr, no setor aqui analisado) atua como empreendedor político nas questões que julga relevantes.

Para que essas ações coletivas possam ser empreendidas, existem 3 dimensões da participação do empresariado no policy-making: 1) participação (coletiva e organizada ou individual e dispersa); 2) forma de entrada (formal e aberta ou informal e opaca); e 3) canais de participação/influência (conselhos consultivos ou deliberativos, barganha corporativista, lobby, financiamento de campanha e partidário, nomeações no governo ou corrupção de facto). Em geral, o empresariado não utiliza um único tipo de canal de participação, procurando distribuir de forma equilibrada seu "portfólio de investimentos" políticos em diversas atividades, dependendo das oportunidades de influência percebidas/oferecidas pelo sistema político e dos maiores retornos possíveis. Sendo que tais oportunidades podem ser dificultadas por características institucionais de longa data do sistema político e/ou podem ser criadas ou fechadas por formuladores de políticas individualmente. (SCHNEIDER, 2010, p. 312-3). 
Dessa forma, o sucesso das ações políticas do empresariado depende do local no qual a ação é empreendida. $\mathrm{Na}$ CS, apesar de uma preponderância inicial da Associtrus e da tentativa de resolver os problemas do setor, as discussões e soluções passam desde 2010 pelo entendimento entre Associtrus e CitrsBr, o que muitas vezes significa reveses para a Associtrus. Logo, nesse espaço dentro do MAPA, a ação dos empresários das maiores indústrias de suco de laranja tem obtido mais sucesso em comparação com a ação dos produtores de laranja, como será discutido na próxima seção. Portanto, essa vertente que estuda a atuação política empresarial nos parece a mais adequada ao estudo dos grupos citrícolas.

\section{A CÂMARA SETORIAL DA CITRICULTURA NO MINISTÉRIO DA AGRICULTURA, PECUÁRIA E ABASTECIMENTO ENTRE 2004-2018}

A instalação da CS da Citricultura do MAPA ocorre em 16 de julho de 2004 em Bebedouro$\mathrm{SP}^{18}$ na tentativa de valorização do setor (VILELA; ARAÚJO, 2006). Segundo Borges e Costa (2005), a CS do MAPA foi fruto da reivindicação da Associtrus, que se reorganizara em setembro de 2003 com sede novamente em Bebedouro-SP ${ }^{19}$. Paulillo (2006, p.105) também acredita que as "ações coletivas da citricultura, lideradas pelas novas ações da Associtrus, pressionam a reorganização política e econômica do setor”. A indicação do presidente da Associtrus, Flávio de Carvalho Pinto Viegas, para a presidência da CS pode ser um indicativo desse argumento. Como Secretário Executivo da CS foi escolhido um pesquisador do Centro APTA Citros Sylvio Moreira, do Instituto Agronômico da SAA-SP, Marcos Antônio Machado. Desse modo, Viegas representava o setor privado e Machado o setor público na direção da Câmara, contudo, entre órgãos públicos (como outros ministérios, Embrapa, BNDES, universidades) e entidades privadas (como SRB, Federação da Agricultura e Pecuária do Estado de São Paulo - FAESP), mais 29 entidades ainda compunham a CS em 2006 (VILELA; ARAÚJO, 2006). Entretanto, somente 22 entidades, sendo 15 privadas e 7 públicas participaram das 10 reuniões da CS entre 2004 e 2005 (GUANZIROLI; BASCO; ORTEGA, 2007) ${ }^{20}$.

\footnotetext{
18 Oficialmente criada pela Portaria n.516 de 22 de dezembro de 2005 (VILELA; ARAÚJO, 2006).

${ }^{19}$ A Associtrus foi criada em 1974 como “Associação Paulista de Citricultores”, com sede em Bebedouro-SP. Em 1983 torna-se "Associação Brasileira de Citricultores" e sua sede altera-se para São Paulo-SP. Suas atividades foram reduzidas a partir de 1995 até se tornar inativa em 1996 devido à falta de financiamento e de apoio dos citricultores. (ASSOCRITRUS, 2005; RODRIGUES, 1995; VIERA; ALVES, 1997)

${ }^{20}$ A partir de 2008, com a reformulação do Consagro, somente 25 membros efetivos passam a ser permitidos nas CS e membros ausentes em 3 reuniões consecutivas tornaram-se passíveis de exclusão. Outras alterações foram "a possibilidade de a presidência ser assumida por membros do governo, a definição do mandato, que será de dois anos, com recondução por igual período" (REFORMULAÇÃO DAS..., 2008).
} 
Desde sua formação, a CS da citricultura procurou discutir a "formulação e execução de políticas específicas para o setor, que considerem a cadeia como um todo, além do acordo entre produtor e a indústria de sucos para definição de contrato que dê garantias de preços para a laranja" (VILELA; ARAÚJO, 2006, p.265). O conflito entre citricultores e indústrias processadoras de suco de laranja sobre o preço da caixa de laranja torna-se latente nos anos 1960, sendo solucionado em 1985 com o estabelecimento do contrato padrão ${ }^{21}$. Porém, já em 1991, esse contrato deixa de ser efetivo, sendo abandonado em 1994, reavivando o conflito. (BORGES; COSTA, 2005/2006; MAIA, 1992; PAULILLO, 2006; RODRIGUES, 1995)

Concomitantemente ao fim do contrato padrão, ocorreu uma grande concentração industrial no setor entre 1990 e 2012: das 12 indústrias processadoras existentes em 1990, esse número caiu para 4 em 2004 e depois para 3 em 2012²2 (PAULILLO, 2006; VILELA; ARAÚJO, 2006). Assim, a diminuição no número de indústrias processadoras de suco de laranja e a verticalização a jusante dessa indústria, ocasionou perdas e queda na renda de citricultores (PAUliLlO, 2006). Em reação, desde 2000, os citricultores procuraram criar um novo contrato para o preço da caixa de laranja que fosse justo para os produtores, o qual passou a ser chamado em 2005 de Conselho de Produtores e Exportadores de Suco de Laranja (Consecitrus), recebendo o apoio da CS para sua concretização (ASSOCITRUS, 2014).

Todavia, a

ABECITRUS [...] teria deixado de participar [da CS em 2005] porque, aparentemente, não se interessa nesta regulação. A [CS] dedica-se a resolver questões como impostos, importação, classificação, mas não discute os grandes problemas da cadeia produtiva, que giram em torno da redistribuição da renda no interior da cadeia. (GUANZIROLI; BASCO; ORTEGA, 2007, p.13)

Somente em novembro de 2009, as indústrias decidem solicitar sua reinclusão na CS, por meio de sua nova entidade de representação, a CitusBr. Para tanto, exigem que a presidência da CS não fosse mais ocupada pelo presidente da Associtrus (VIEGAS, 2010). Viegas então "na esperança de que problemas como falta de informação, transparência, concorrência e excessiva concentração e verticalização do setor industrial [fossem] resolvidos, de modo que se possa avançar na governança do setor” (BRASIL, 2009) passa a presidência da Câmara a um representante do

\footnotetext{
${ }^{21}$ O contrato padrão ou contrato de participação foi estabelecido na safra 1986/87 e foi utilizado até a safra 1994/95, por meio do qual "o preço da caixa da laranja [era atrelado] à média anual do preço de mercado registrado pela Bolsa de Valores de Nova Iorque. Assim, os produtores poderiam participar das oscilações dos preços decorrentes das geadas da Flórida.” (BORGES; COSTA, 2005/2006, p.112)

22 As 4Cs de 2004, Suco Cítrico Cutrale Ltda.; Citrosuco Ltda. - Grupo Fisher; Citrovita Ltda. - Grupo Votorantim; e Coinbra - Louis Dreyfus Commodities, tornaram-se as 3Cs em 2012 com a fusão entre Citrosuco e Citrovita.
} 
MAPA. A fala de Viegas se justifica devido ao grande poder político e econômico que as indústrias processadoras possuem, como visto na figura 2 (PAULILLO, 2006). Isso porque o "segredo da coordenação do setor citrícola no Brasil está na existência e na vitalidade de uma rede política que opera em torno dos interesses das grandes empresas de processamento de suco de laranja" (PAULILLO, 2006, p.61), ou seja, dos interesses do empresariado industrial citrícola. O que tem corroborado com a percepção dos citricultores da necessidade de uma atuação estatal para o setor, bem como da necessidade de ações coletivas entre os mesmos.

Imagem 2 - Rede de poder citrícola paulista após 2009

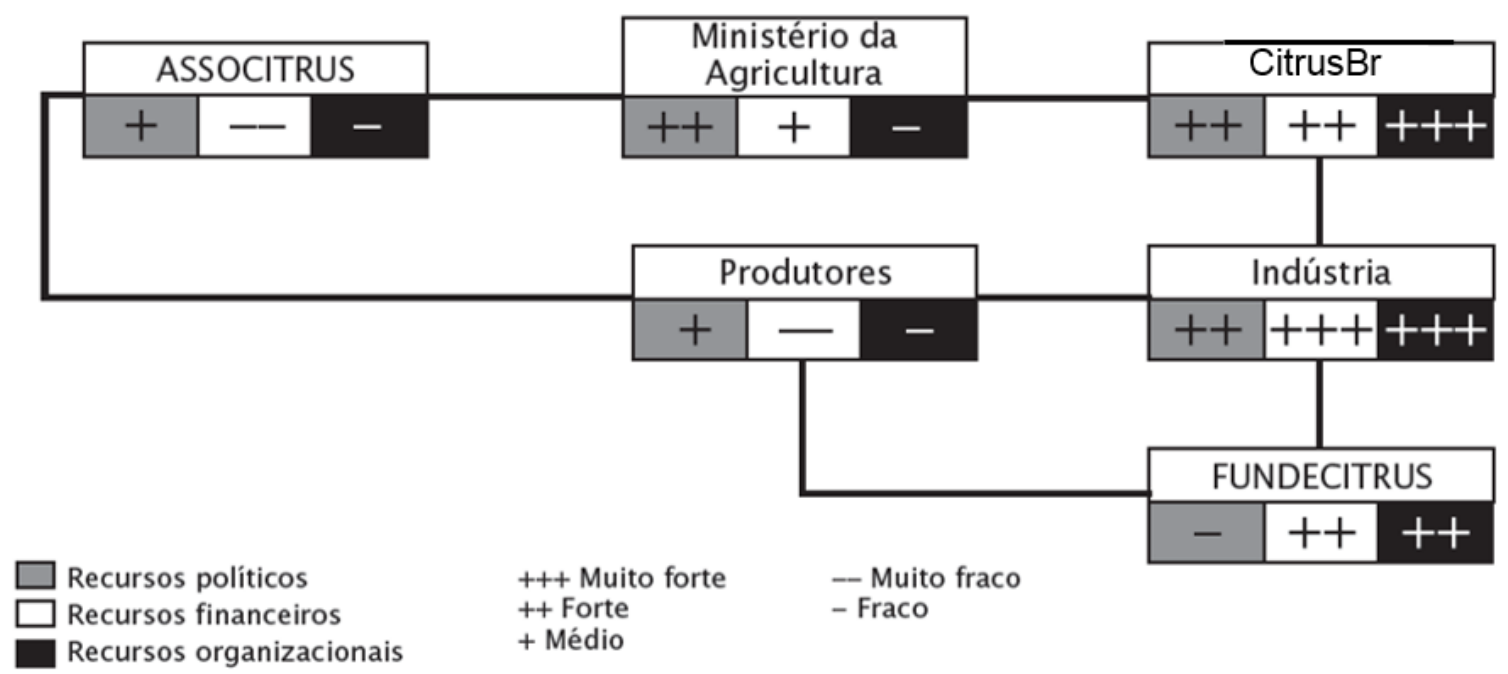

Fonte: adaptado de Paulillo (2006, p.107).

Outro fator conjuntural do setor citrícola relevante para a instalação da Câmara no MAPA foi a chegada de nova doença aos pomares em 2004 - o greening, a doença mais destrutiva dos citros e a maior ameaça à citricultura mundial (FUNDECITRUS, 2019). Isso porque se as plantas infectadas forem novas "não chegam a produzir e as adultas em produção sofrem uma grande queda prematura de frutos e definham ao longo do tempo" (FUNDECITRUS, 2019). Além disso, plantas infectadas podem servir de alimento para insetos vetores que infectarão plantas sadias, por isso, no Brasil é obrigatória a eliminação das árvores infectadas, dado que ainda hoje não existe cura para essa doença (FUNDECITRUS, 2019). Logo, entre 2004 e 2005, quando o greening chegou aos Estados Unidos $^{23}$, a citricultura entra em uma crise global, o que reestimula a Associtrus a demandar ações estatais.

\footnotetext{
${ }^{23}$ O greening afeta a citricultura do Brasil, Argentina, Paraguai, México, Estados Unidos e quase todos os países da América Central e Caribe (FUNDECITRUS, 2019).
} 
Ao analisar o setor citrícola, percebemos que mais uma vez um problema fitossanitário mobiliza a organização dos citricultores em associações representativas e a aproximação entre setor privado e público para definição de políticas públicas. Isso porque, em junho de 1974, a criação da Associtrus foi estimulada pelo Estado brasileiro por meio da "Campanha Nacional Contra o Cancro Cítrico" (CNCCC), dado que os citricultores deveriam participar por meio de associações (RODRIGUES, 1995). Desse modo, o surgimento da Associtrus, e da entidade representante da indústria no período, a Associação Brasileira da Indústria de Suco Cítricos (Abrassucos) ${ }^{24}$, não teria sido totalmente espontâneo, baseando-se na relação com o Estado e na colaboração recíproca ${ }^{25}$.

Borges e Costa (2005/2006) mostram que a consolidação do setor ocorreu em meio a participação e a retração do Estado. Em relação aos momentos de participação estatal, tem-se uma atuação primária do governo estadual de São Paulo, que cria o Serviço de Citricultura e as Estações Experimentais (1920) e tenta estabelecer o preço mínimo para a caixa da laranja (1940-50); na sequência, a atuação do governo federal que procurou regular o setor em dois momentos (1970 e 2000 $)^{26}$, sendo necessária em ambos os momentos a participação das associações de representação de interesses. Entretanto, o Estado não tem conseguido superar às assimetrias entre citricultores e indústrias processadoras, mesmo dentro da CS, onde as indústrias possuem somente uma entidade representativa e os citricultores várias (VILELA; ARAÚJO, 2006).

Nesse sentido, a classificação de Guanziroli, Basco e Ortega (2007) da CS da Citricultura como uma cadeia de difícil regulação é considerada correta. Entretanto, apesar de ser uma câmara com propostas de estruturação e de longo prazo para o setor, parece-nos mais correto classificá-la como câmara reivindicativa e não pró-ativa como fazem os autores. Tal percepção, evidencia-se pela análise das atas das reuniões ordinárias CS da Citricultura entre outubro de 2007 e outubro de 2018, como será visto adiante.

\section{ANÁLISE DE CONTEÚDO DAS ATAS DA CS DA CITRICULTURA DO MAPA}

Para verificar como a Associtrus, Abecitrus e CitrusBr participaram e utilizaram a CS da Citricultura do MAPA, visando manutenção ou criação de benefícios a seus associados, e assim atingir o objetivo deste trabalho, foi realizada uma análise de conteúdo das Atas da câmara de

\footnotetext{
${ }^{24}$ Fundada em dezembro de 1974.

${ }^{25}$ Para Rodrigues (1995), esse momento nos anos 1970 marca a consolidação do corporativismo societal no complexo citrícola, sendo o resultado da adaptação do setor à nova dinâmica agrícola brasileira com o enfraquecimento do associativismo tradicional

${ }^{26}$ Os anos 1960, 1980 e 1990 são marcados pela retração da atuação do Estado (BORGES; COSTA, 2005/2006).
} 
29/10/2007 a 16/10/2018, totalizando 40 Atas, pois as Atas de 2004 a 2006 não estão disponíveis em arquivo eletrônico ${ }^{27}$. Contudo, isso não representou grande prejuízo na presente análise, pois, segundo Guanziroli, Basco e Ortega (2007), que analisou as Atas de 2004 a 2006, entre 2004 e 2005, ocorreram 10 reuniões da CS da Citricultura e eram projetadas 2 reuniões para 2006. Entretanto, a Ata da 11 ${ }^{\text {a }}$ Reunião da referida câmara ocorreu em 29 de outubro de 2007, ou seja, as reuniões previstas para 2006 não ocorreram.

Nessa perspectiva, dado que o trabalho se embasou em documentos oficiais, faz-se necessário primeiramente diferenciar análise de conteúdo da análise documental. Segundo Santos (2012, p.384), a análise de conteúdo diferencia-se da análise documental, pois a primeira foca nas mensagens e objetiva usar as "mensagens para confirmar os indicadores que permitam inferir sobre outra realidade que não a da mensagem". Por sua vez, a análise documental foca-se em documentos e objetiva a "representação condensada da informação para consulta e armazenagem" (SANTOS, 2012, p.384). Logo, como o objetivo proposto aqui não é condensar as Atas para armazenagem, mas sim utilizá-las para compreender a realidade da CS, a análise de conteúdo foi a metodologia utilizada.

De acordo com Bardin (1977), análise de conteúdo é referente a

Um conjunto de técnicas de análise das comunicações visando obter, por procedimentos, sistemáticos e objetivos de descrição do conteúdo das mensagens, indicadores (quantitativos ou não) que permitam a inferência de conhecimentos relativos às condições de produção/recepção (variáveis inferidas) destas mensagens. (BARDIN, 1977$, p.42) $)^{28}$

Seramim e Walter (2017, p.245) destacam que a análise de conteúdo "concentra-se sobre o assunto e contexto e enfatiza as diferenças e semelhanças entre os códigos e as categorias, [...] analisando o conteúdo manifesto [o que o texto diz] e latente [sobre o que o texto está falando] num texto”. Para a realização de uma análise de conteúdo, Bardin (1977) indica três procedimentos: pré-análise; exploração do material; e tratamento dos resultados e interpretação. Na etapa de préanálise, deve ser realizada uma leitura do material e estabelecidos objetivos e hipóteses. Na etapa de exploração do material, devem ser estabelecidas as unidades e categorias de análise, que podem ser um tema, palavra ou frase. Já na etapa de tratamento dos resultados e interpretação

o pesquisador procurará torná-los significativos e válidos. Utilizando técnicas quantitativas e/ ou qualitativas, condensará tais resultados em busca de padrões,

\footnotetext{
27 As Atas foram obtidas via Lei de Acesso à Informação (LAI), Lei no 12.527/2011.

${ }^{28}$ Embora Seramim e Walter (2017, p.245) afirmem que a própria Bardin contesta essa afirmação, já que "a intenção é inferir conhecimentos relativos às condições de produção (ou de recepção, eventualmente), que pode ocorrer por meio de indicadores quantitativos ou não".
} 
tendências ou relações implícitas. Esta interpretação deverá ir além do conteúdo manifesto dos documentos, pois [,,] interessa ao pesquisador o conteúdo latente, o sentido que se encontra por trás do imediatamente apreendido. (GODOY, 1995, p.24)

Neste trabalho, a primeira etapa de Bardin se caracterizou pela leitura das Atas, que foi realizada após a pesquisa bibliográfica sobre o setor, as CS do MAPA e a CS da Citricultura, gerando objetivos, hipóteses e expectativas acerca do comportamento dos atores dentro da CS. Desse modo, na segunda etapa, foram criadas unidades e categorias de análise baseadas em temas (conteúdo manifesto e conteúdo latente, respectivamente) e, na sequência, foram verificadas suas incidências e consequências/desenvolvimentos ao longo do tempo. Por fim, na última etapa, foi criada a tabela 1 com as unidades e categorias de análise, suas discussões e seus resultados, e foi realizada a interpretação desses dados na sequência.

Tabela 1 - Sistematização das discussões na CS da Citricultura (2007-2018)

\begin{tabular}{|c|c|c|}
\hline $\begin{array}{l}\text { Tema (conteúdo } \\
\text { latente) }\end{array}$ & $\begin{array}{l}\text { Discussões na CS (conteúdo } \\
\text { manifesto) }\end{array}$ & Resultado (ações) \\
\hline $\begin{array}{l}\text { Programas de } \\
\text { agricultura familiar }\end{array}$ & $\begin{array}{l}\text { Proposta de realização de seminários } \\
\text { sobre citricultura familiar nos estados, } \\
\text { organizados pelo Ministério do } \\
\text { Desenvolvimento Agrário (MDA) } \\
\text { (2008). }\end{array}$ & $\begin{array}{l}\text { Programação para realização de } \\
\text { seminários nos estados produtores de } \\
\text { citros realizado pela Embrapa (2008). } \\
\text { Apresentação do MDA das políticas } \\
\text { públicas de financiamento e proteção da } \\
\text { produção para a agricultura familiar } \\
(2011) \text {. }\end{array}$ \\
\hline $\begin{array}{l}\text { Problemas } \\
\text { fitossanitários }\end{array}$ & $\begin{array}{l}\text { Desde } 2009 \text { ocorre discussão sobre } \\
\text { indenização por erradicação de } \\
\text { árvores doentes. }\end{array}$ & $\begin{array}{l}\text { Criação de grupo de trabalho (GT), que } \\
\text { conclui pelo pagamento ( } 2009) \text {, o qual } \\
\text { não ocorreu dentro do período } \\
\text { analisado. } \\
\text { A partir de 2012, a percepção dos } \\
\text { órgãos governamentais mudou e } \\
\text { decidiram não erradicar mais as árvores } \\
\text { com greening, somente utilizar o } \\
\text { manejo, pois seria preciso erradicar } \\
\text { todos os pomares. } \\
\text { Proposta de elaboração de um Plano } \\
\text { Nacional Contra o Greening (2017). }\end{array}$ \\
\hline $\begin{array}{l}\text { Consumo de fruta } \\
\text { e suco }\end{array}$ & $\begin{array}{l}\text { Percepção de queda no consumo da } \\
\text { fruta no Brasil (2008). } \\
\text { CitrusBr expõe queda no consumo } \\
\text { mundial (2010). } \\
\text { Associtrus demonstra crescimento na } \\
\text { demanda por suco (2011). }\end{array}$ & $\begin{array}{l}\text { Pedido para a Frente Parlamentar da } \\
\text { Agricultura incluir o suco de laranja na } \\
\text { merenda escolar (2007). } \\
\text { Campanha sobre benefícios do suco em } \\
\text { Sergipe, incluindo o suco de laranja na } \\
\text { merenda escolar (2009). } \\
\text { CitrusBr sugere às escolas incluir suco } \\
100 \% \text { na merenda }(2015) \text {. } \\
\text { Projeto Apex-CitrusBr }{ }^{29}(2010) \text {. }\end{array}$ \\
\hline
\end{tabular}

\footnotetext{
${ }^{29}$ Campanha "Be Orange", cujo público alvo foram os consumidores do Reino Unido, uma parceria Apex-Brasil e CitrusBr.
} 
Campanha "Fruit Juice Matters" (2017-

18).

\begin{tabular}{ll}
\hline Previsão de safra & Companhia Nacional de \\
& Abastecimento (CONAB) começa a \\
& realizar levantamento de estimativa de \\
& safra após discussões na CS, mas sem \\
& os dados dos pomares das indústrias \\
& (2010). Em 2011, a CitrusBr também \\
& realiza esse levantamento e continua a \\
& não fornecer dados à CONAB.
\end{tabular}

A CONAB deixa de fazer o

levantamento devido à falta de recursos

em 2014. O órgão pediu materiais para a

CitrusBr que não cedeu.

Fundecitrus passa a realizar o

levantamento no estado de São Paulo

(2015).

Cada região/estado faz sua previsão (2016-17).

\begin{tabular}{|c|c|c|}
\hline $\begin{array}{l}\text { Preço da caixa de } \\
\text { laranja e Linha } \\
\text { Especial de } \\
\text { Crédito (LEC) } \\
\text { para produção de } \\
\text { laranja }\end{array}$ & $\begin{array}{l}\text { Discussão sobre preços praticados } \\
\text { pela indústria (2010). } \\
\text { Discussão sobre estender para outros } \\
\text { estados além de São Paulo o preço } \\
\text { fixado pelo governo (2014). } \\
\text { Discussão sobre variação no } \\
\text { pagamento da caixa feito pela } \\
\text { indústria (2015). }\end{array}$ & $\begin{array}{l}\text { Disponibilização de crédito aos } \\
\text { citricultores desde que a caixa da laranja } \\
\text { fosse comprada à } 8 \text { reais }(2009) \text {. } \\
\text { LEC para Preço de Referência da Caixa } \\
\text { de Laranja }(\mathrm{R} \$ 10,50) \text { que também } \\
\text { poderia financiar estoque de suco ( } 2011 \\
\text { e 2012). }\end{array}$ \\
\hline $\begin{array}{l}\text { Renegociação de } \\
\text { dívidas }\end{array}$ & $\begin{array}{l}\text { Banco do Brasil suspende custeio de } \\
\text { citricultores sem contratos com as } \\
\text { indústrias (2009). } \\
\text { Nova dificuldade no acesso ao crédito } \\
\text { (2015). }\end{array}$ & $\begin{array}{l}\text { Proposta de renegociação apresentada } \\
\text { no MAPA pelo deputado Mendes } \\
\text { Thame (2012). }\end{array}$ \\
\hline Consecitrus & $\begin{array}{l}\text { Nas reuniões iniciais, participam } \\
\text { CitrusBr, SRB, Associtrus e FAESP, } \\
\text { porém, em reuniões posteriores a } \\
\text { Associtrus não é convidada (2011). } \\
\text { Posteriormente, FAESP também se } \\
\text { desentende com CitrusBr e SRB. } \\
\text { Consecitrus é criado em } 2012 \text { tendo } \\
\text { como membros SRB e CitrusBr. } \\
\text { FAESP pede que apenas instituições } \\
\text { com mais de } 5 \text { anos sejam membros } \\
\text { do órgão, o qual deveria ser regional } \\
\text { (2014). } \\
\text { CitrusBr e Associtrus anunciam que o } \\
\text { estatuto está em negociação (2015). }\end{array}$ & $\begin{array}{l}\text { Pedido do presidente do Consecitrus, } \\
\text { João Sampaio Filho }{ }^{30} \text {, que questões de } \\
\text { representatividade fossem adiadas para } \\
\text { que o órgão pudesse começar a } \\
\text { funcionar (2013). } \\
\text { Rejeição pelo Conselho Administrativo } \\
\text { de Defesa Econômica (CADE) em } \\
\text { setembro/2018 da existência do } \\
\text { Consecitrus. }\end{array}$ \\
\hline $\begin{array}{l}\text { Responsabilidade } \\
\text { pela colheita }\end{array}$ & $\begin{array}{l}\text { CNA e Associtrus não concordam com } \\
\text { a decisão do Ministério do Trabalho de } \\
\text { passar responsabilidade para indústria } \\
\text { (2010). } \\
\text { CitrusBr informa desejo de participar } \\
\text { de treinamento sobre colheita dado } \\
\text { pelo MAPA (2015). }\end{array}$ & - \\
\hline $\begin{array}{l}\text { Política Pública } \\
\text { para citricultura }\end{array}$ & Formado GT (2012). & - \\
\hline
\end{tabular}

Fonte: elaboração própria com base nas atas das reuniões da CS da Citricultura (outubro/2007 a outubro/2018).

${ }^{30}$ Foi secretário de Agricultura e Abastecimento do Estado de São Paulo entre 2007 e 2011. 
Conforme a análise das atas, e apesar de as CS representarem o sistema corporativista, a CS discutiu poucas vezes temas que afetam os trabalhadores rurais: em nenhuma das atas foi tratado sobre uma renda mínima a colhedores de laranja e somente em uma foi discutido um projeto de lei sobre regulamentação do trabalho rural. Mesmo para pequenos citricultores a atenção da CS é baixa.

Pela sistematização das atas, percebeu-se também que, mesmo os grandes problemas do complexo (estimativa de safra e preço da caixa de laranja) sendo discutidos na CS, a partir da entrada da CitrusBr na CS, os temas que afetam negativamente a cadeia de forma ampla (como por exemplo as questões fitossanitárias dos pomares, as barreiras à exportação do suco industrializado e a queda no consumo desse suco) não suscitam discussões de membros com posições extremamente divergentes. Nesses temas, ocorre, em grande medida, troca de informações e reafirmação de posições, caso do combate ao greening.

Todavia, nos temas em que há assimetria no domínio de informações ${ }^{31}$ (como por exemplo nas estimativas de previsão de safra e de consumo, que afetam o estabelecimento do preço da caixa de laranja e a formação do Consecitrus) há divergências marcantes entre a posição da Associtrus e da CitrusBr. Destacam-se nesse embate discussões, em mais de uma ocasião, entre as duas associações acerca do consumo de suco de laranja no mundo (que para a CitrusBr está em queda, já para a Associtrus não) e as estimativas de safra e estoque de suco (a CitrusBr utiliza metodologia própria e a Associtrus dados do Departamento de Agricultura dos Estados Unidos - USDA).

A criação do próprio Consecitrus suscitou diversos confrontos: inicialmente proposto pela Associtrus, foi negado pela Abecitrus, mas passa a ser estimulado e liderado pela CitrusBr a partir de 2011, ocasionando a contratação de consultorias e até a não participação da Associtrus. Tal mudança na posição dos representantes da indústria, justifica-se por uma decisão do CADE, órgão que condicionou sua aceitação da fusão da Citrovita a Citrosuco à criação do Consecitrus, o que ocorreu em 2012. Porém, seu funcionamento somente foi autorizado com ressalvas em fevereiro de 2014 e sua existência rejeitada pelo CADE em 2018 pela ausência de elaboração de um estatuto, impedindo o funcionamento do Conselho. (BRASIL, 2014; ESTADÃO, 2018; ISTOÉ, 2017).

Por fim, cabe ainda ressaltar que se a Associtrus foi peça fundamental para a criação da CS no MAPA, em outubro de 2018 a associação foi excluída da câmara por possuir três faltas consecutivas (nas reuniões de março, junho e outubro de 2018). Entretanto, desde a reformulação das CS em 2008, diversos membros se ausentaram em mais de duas ou três reuniões consecutivas

\footnotetext{
${ }^{31}$ Conforme discutido acerca do complexo como um todo por Paulillo (2006), as indústrias são as detentoras das informações mais precisas sobre safra e produção.
} 
e antes da realização de suas exclusões, esses membros foram notificados sobre tal possibilidade e a decisão tomada em reuniões posteriores ${ }^{32}$ - o que não ocorreu com a Associtrus. Nessa perspectiva, o principal benefício perdido dentro da CS pela Associtrus foi sua exclusão da câmara. Já para a CitrusBr a participação na CS não modificou seus benefícios dentro do complexo citrícola, os quais foram mantidos.

\section{CONSIDERAÇÕES FINAIS}

Como abordado anteriormente, as CS representam resquícios do sistema corporativista no Brasil sendo um canal de interlocução entre indústrias e governo (algumas vezes incluindo os trabalhadores). No caso da CS da Citricultura, além de indústrias e governo participam quase todos os elos do complexo - viveiristas, entidades de pesquisa, citricultores, cooperativas - mas, ainda ficam de fora os trabalhadores rurais. Embora sua criação seja fruto da reorganização da associação de representação de interesse dos citricultores (Associtrus), sua "rival", a CitrusBr, foi quem obteve mais benefícios com a CS. O que indica que a CitrusBr tem atuado como o elo forte da cadeia e assumido muitas vezes o papel de empreendedor político dentro e fora da CS, devido aos recursos financeiros, políticos e organizacionais que reúne. Isso porque as indústrias processadoras acabam financiando toda a cadeia em decorrência da dificuldade do setor público em gerar crédito satisfatório para todos os citricultores.

Logo, a CS discutiu primordialmente problemas fitossanitários, o endividamento e financiamento do citricultor, o preço da caixa de laranja e o Consecitrus. No entanto, esses temas não foram tratados da mesma forma. No tocante aos problemas fitossanitários, houve um certo consenso entre as atividades a serem tomadas e trocas de informações entre os membros. Já em relação ao endividamento e financiamento do citricultor, ocorreram divergências e questionamentos sobre o tratamento recebido por São Paulo (que teria mais valores destinados, mas ainda não suficientes) em detrimento de outros estados. Por fim, sobre o preço da caixa de laranja e o Consecitrus algumas propostas foram discutidas, mas todas dependiam de órgãos de fora da CS e consequentemente não avançaram.

Nessa perspectiva, parece que a CS serve muito mais de espaço reivindicativo para afirmação e cobrança de demandas que um espaço de "propostas de estruturação para o setor e de longo prazo" (GUANZIROLI; BASCO; ORTEGA, 2007). É inegável que os membros da CS da

\footnotetext{
${ }^{32}$ Entre os casos temos: CEAGESP em 2011; ABCVS, SEAB/PR, SINDAG e SEAGRI/SE em 2012.
} 
Citricultura possuem conhecimento dos entraves do complexo, todavia, a falta de regulação do setor barrada até 2011 pela CitrusBr, que depois incentiva-a, não permite que a CS avance em temas importantes, como a proposta de uma Agenda Estratégica. Desse modo, como não ocorreram avanços em políticas derivados das discussões na CS não é possível verificar em que medida a Associtrus e a CitrusBr tiveram suas demandas beneficiadas ou prejudicadas diretamente. Todavia, uma manutenção no status quo do setor beneficia a CitrusBr e a exclusão da Associtrus da CS prejudica-a por perder um espaço que havia criado e liderado e que representa o espaço de interlocução entre os diversos elos da cadeia.

\section{REFERÊNCIAS}

ABRANCHES, S. (2009). Conselho de Desenvolvimento Industrial (CDI). CPDOC, Verbetes. Disponível em <http://www.fgv.br/cpdoc/acervo/dicionarios/verbete-tematico/conselho-dedesenvolvimento-industrial-cdi>. Acesso em 31 jun. 2019.

ANDERSON, P. (1999). Câmaras setoriais: histórico e acordos firmados - 1991/95. Rio de Janeiro: IPEA. (Texto para Discussão, n. 667).

ARBIX, G. A. T. (1995). Uma aposta no futuro: os três primeiros anos da câmara setorial da indústria automobilística e a emergência do meso-corporatismo no Brasil. São Paulo. Tese (Doutorado). Universidade de São Paulo.

ASSOCITRUS. (2005). Informativo Associtrus, Edição Especial, Ano 2, n. 4. Disponível em $<$ http://www.associtrus.com.br/informativos/04_edicaoespecial.pdf>.

ASSOCITRUS. (2014). Informativo Associtrus. Ano 10, n. 52. Disponível em <http://www.associtrus.com.br/informativos/52-Abri-Maio-2014.pdf>.

AVICULTURA INDUSTRIAL. (2008). Reformulação das câmaras fortalece parceria entre governo e setor privado. Disponível em:

<https://www.aviculturaindustrial.com.br/imprensa/reformulacao-das-camaras-fortaleceparceria-entre-governo-e-setor-privado/20080731-085908-3338>.

BARDIN, L. (1977). Análise de conteúdo. Lisboa: Edições 70, 1977.

BEEFPOINT. Giro do Boi. (2003). Mapa Recriará Conselho Nacional de Política Agrícola. Disponível em <https://www.beefpoint.com.br/mapa-recriara-conselho-nacional-de-politica-agricola$3533 />$.

BEEFPOINT. Giro do Boi. (2003). Rodrigues Instala Conselho do Agronegócio. Disponível em $<$ https://www.beefpoint.com.br/rodrigues-instala-conselho-do-agronegocio-3205/>. 
BORGES, A. C. G., COSTA, V. M. H. M. (2005). "Conflitos, Crises, Competitividade e Coordenação: Atuação e Perspectivas dos Agentes do Agronegócio Citrícola”. In: XLIII Congresso da SOBER. Ribeirão Preto.

BORGES, A. C. G., COSTA, V. M. H. M. (2005/2006). A evolução do agronegócio citrícola paulista e o perfil da intervenção do Estado. Revista Uniara, n.17/18.

BRASIL. Ministério da Agricultura, Pecuária e Abastecimento. (2009a). As Câmaras do Mapa: um instrumento democrático e transparente de interlocução com a sociedade. Secretaria Executiva. - Brasília: Mapa/ACS.

BRASIL. Ministério da Agricultura, Pecuária e Abastecimento. (2009b). Secretária-Executiva. Conselho do Agronegócio. Câmara Setorial da Cadeia Produtiva de Citricultura. Ata da 19a Reunião Ordinária.

BRASIL. Ministério da Agricultura, Pecuária e Abastecimento (2007-2018). Sistema de Gestão de Câmaras Setoriais e Temáticas. Assessoria de Apoio às Câmaras Setoriais e Temáticas. Câmara Setorial da Cadeia Produtiva da Citricultura. Reuniões Ordinárias n. 11 a 37, 39, 40, 42, 43, 45, 46, 48,50 a 55.

BRASIL. Conselho Administrativo de Defesa Econômica - CADE. (2014). Cade define como será constituição do Consecitrus. Notícias, regulamentação. Disponível em $<$ http://www.cade.gov.br/noticias/cade-define-como-sera-constituicao-do-consecitrus $>$. Acesso em 19 jul. 2018.

CAVALCANTE, P., LOTTA, G. S., OLIVEIRA, V. E. (2018). Do insulamento burocrático à governança democrática: as transformações institucionais e a burocracia no Brasil. In: PIRES, R., LOTTA, G., OLIVEIRA, V. E. (Orgs.). Burocracia e políticas públicas no Brasil: interseções analiticas. 1ed.brasília: IPEA/ENAP.

DINIZ, E. (1999). Globalização, elites empresariais e democracia no Brasil dos anos 90. Ensaios FEE, vol. 20, n 1, p. 155-178.

DINIZ, E., BOSCHI, R. (2000). Empresários e Poder Legislativo no Brasil contemporâneo. Texto apresentado no Seminário Temático "Instituições Políticas". In: XXIV Encontro Anual da ANPOCS. Petrópolis. Disponível em:

$<$ https://www.anpocs.com/index.php/encontros/papers/24-encontro-anual-da-anpocs/gt22/gt06-6/4760-elidiniz-empresarios/file> .

FUNDECITRUS. O que é greening? Doenças, Greening Huanglongbing. Disponível em <https://www.fundecitrus.com.br/doencas/greening>. Acesso em 22 mar. 2019.

GODOY, A. S. (1995). Pesquisa qualitativa: tipos fundamentais. Revista de Administração de Empresas, vol. $35, n^{\circ} 3$, p. $20-29$.

GUANZIROLI, C. E., BASCO, C. A., ORTEGA, M. (2007). Regulação ou cooptação? A ação do Ministério de Agricultura e Pecuária (MAPA) através das Câmaras Setoriais e Temáticas da 
agricultura entre 2002 e 2006. In: XLV Congresso da Sociedade Brasileira de Economia, Administração e Sociologia Rural. Londrina.

IGLECIAS, W. (2007). O empresariado do agronegócio no Brasil: ação coletiva e formas de atuação política - as batalhas do açúcar e do algodão na OMC. Revista de Sociologia Política, $\mathrm{n}^{\circ}$ 28, p. 75-97.

ISTO É. (2017). Consecitrus completa três anos ainda sob impasse jurídico e sem aval do Cade. Disponível em: http://istoe.com.br/consecitrus-completa-tres-anos-ainda-sob-impasse-juridico-e-sem-aval-docade/. Acesso em 20 mai. 2017.

LESSINGER, E. (2003). Consagro: decisões compartilhadas. Entrevista. Agronegócio, ano 4, n. 26.

MACHADO, A. (2009). A formulação da política comercial externa agrícola: condicionantes internacionais e domésticos da transformação institucional do MAPA. Brasília. Dissertação (Mestrado em Relações Internacionais). Universidade de Brasília, Brasília.

MAIA, M. L. (1992). Citricultura paulista: evolução, estrutura e acordos de preços. Piracicaba. Dissertação (Mestrado em Agronomia). Universidade de São Paulo.

MANCUSO, W. P. (2007). O empresariado como ator político no Brasil: balanço da literatura e agenda de pesquisa. Revista de Sociologia Política, n 28, p. 131-146.

MENDONÇA, S. R. (2005). Estado e hegemonia do agronegócio no Brasil. História e Perspectivas, vol. $1, \mathrm{n}^{\circ} 3233$, p. 91-132.

MIRANDA, S. H. G., CUNHA FILHO, J. H., BURNQUIST, H. L., BARROS, G. S. A. C. (2004). Normas sanitárias e fitossanitárias: proteção ou protecionismo. Informações Econômicas, vol. 34, $\mathrm{n}^{\circ} 2$.

MOURA, D., BRISOLA, M. V. (2010). O Agronegócio e a Câmara Setorial no Brasil - um modelo a ser seguido. In: $48^{\circ}$ Congresso da Sociedade Brasileira de Economia, Administração e Sociologia Rural (SOBER). Campo Grande.

O ESTADO DE SÃO PAULO. 2003. Conselho do Agronegócio incentivará câmaras setoriais, Economia e Negócios.

Disponível em <https://economia.estadao.com.br/noticias/geral,conselho-do-agronegocioincentivara-camaras-setoriais,20030220p13421>.

PAULILLO, L. F. et al. (2006). Agroindústria e citricultura no Brasil: diferenças e dominâncias. Rio de Janeiro: E-papers.

PONT, J. V. (2012). Estado e Empresariado Industrial no Brasil: Corporativismo e Representação de Interesses, 1990-2010. Curitiba. Tese (Doutorado em Sociologia). Universidade Federal do Paraná.

REVISTA GLOBO RURAL. (2017). Cade reprova formação do Consecitrus. Disponível em: $<$ https://revistagloborural.globo.com/Noticias/Agricultura/Laranja/noticia/2017/09/cadereprova-formacao-do-consecitrus.html>. Acesso em 19 jul. 2018. 
RISSARDI JÚNIOR, D. J., SHIKIDA, P. F. A., LAGES, A. M. G. (2017). Análise Empírica do Neocorporativismo na Agricultura Canavieira Paranaense. Revista Gesto, vol. 5, n 1.

RODRIGUES, V. L. G. S. (1995). Organizações empresariais por produto: os casos da cana-de-açúcar e da laranja em São Paulo. São Paulo. Tese (Doutorado em Sociologia). Universidade de São Paulo.

SANTOS, F. M. (2012). Análise de conteúdo: a visão de Laurence Bardin. Resenha de: BARDIN, L. Análise de conteúdo. São Paulo: Edições 70, 2011. Revista Eletrônica de Educação, vol. 6, nº 1, p. 383-387.

SERAMIN, R. J., WALTER, S. A. (2017). O que Bardin diz que os autores não mostram? Estudo das produções científicas brasileiras do período de 1997 a 2015. Administração: Ensino e Pesquisa, vol. $18, \mathrm{n}^{\circ} 2$.

SCHMITTER, P. (1974). "Still the Century of Corporatism?” The Review of Politics, vol. 36, nº 1.

SCHMITTER, P. (1993). Some propositions about civil society and the consolidation of democracy. Reihe Politikwissenschaft, Institut für Höhere Studien, Abt. Politikwissenschaft, 10. Wien: Institut für Höhere Studien (IHS), Wien.

SCHMIT'TER, P. (2010). Business and Neocorporativism. In: COEN, D., GRANT, W., WILSON, G. The Oxford Handbook of Business and Government. New York: Oxford University Press.

SCHNEIDER, B. R. (2010). Politics in Latin America: patterns of fragmentation and centralization. In: COEN, D., GRANT, W., WILSON, G. The Oxford Handbook of Business and Government. New York: Oxford University Press.

SILVA, R. O. P., STAUDT, N. P., VERDI, A. R. (2009). Câmaras setoriais do agronegócio paulista: o novo papel do Estado junto à sociedade civil. Informaçôes Econômicas, vol. 39, $\mathrm{n}^{\circ} 4$.

STADUTO, J. A. R., ROCHA JÚNIOR, W. F. da, GONÇALVES JÚNIOR, C. A., ALVES, Y. B. (2007). As câmaras setoriais do agronegócio brasileiro. In: Congresso da Sociedade Brasileira de Economia e Sociologia Rural (SOBER). Londrina.

TAKAGI, M. (2000). Câmaras setoriais agroindustriais, representação de interesses e políticas públicas. Campinas. Dissertação (Mestrado em Desenvolvimento Econômico, Espaço e Meio Ambiente Área de Concentração: Economia Agrícola e Agrária). Universidade Estadual de Campinas.

VEIGA, J. E. (2002). Do crescimento agrícola ao desenvolvimento rural. In: CASTRO, A. C. (Org). Desenvolvimento em Debate (vol. II). Rio de Janeiro: Ed. Mauad/BNDES, 2002. p. 383-409.

VIEGAS, F. (2010). Proposta da Associtrus para um acordo entre citricultores e indústria. Informativo Associtrus, Editorial, Ano 6, n. 31. Disponível em <http://www.associtrus.com.br/informativos/31_agoset2010.pdf>.

VIEIRA, A. C., ALVES, F. J. C. (1997). A Quebra do Contrato Padrão e o Acirramento dos Conflitos no Setor Citrícola. Agricultura em São Paulo, vol. 27, nº 8, p. 7-24.

VILELA, D., ARAÚJO, P. M. M. (Org.) (2006). Contribuições das câmaras setoriais e temáticas à formulação de políticas públicas e privadas para o agronegócio. Brasília: MAPA/SE/CGAC. 
GERALDELLO, C. S. Assimetria de poder na câmara setorial da citricultura do mapa e os grupos de interesse citricola. DOI: http://dx.doi.org/10.5380/recp.v10i2.68282

VINHA, V. G. (1999). O Estado e as Empresas "Ecologicamente Comprometidas" sob a Ótica do Neocorporativismo e do State-Society Synergy approach: o Caso do Setor de Papel e Celulose. Revista Arché Interdisciplinar, Ano 8, n 25, 1999.

VISCARDI, C. M. R. (2018). Corporativismo e Neocorporativismo. Estudos históricos (Rio J.), vol. $31, \mathrm{n}^{\circ}$ 64, p. 243-256. 